\title{
Pelindungan Cagar Budaya Bawah Air dalam Kajian Analisis Hukum
}

\author{
Asyhadi Mufsi Batubara \\ Prodi Arkeologi Fakultas Ilmu Budaya Universitas Halu Oleo Kendari \\ Email :didi_roten@yahoo.co.id
}

\begin{abstract}
Abstrak : Hasil penelitian UNESCO menyebutkan bahwa terdapat \pm 3000 situs kapal karam di perairan Indonesia. Pernyataan ini juga diperkuat oleh posisi strategis negara kepulauan Indonesia yang berada pada jalur persilangan dua benua dan dua samudera, sehingga sejak dahulu telah berperan sebagai jalur perdagangan internasional yang ramai dilayari. Kondisi dan potensi ini merupakan berkah sekaligus menjadi masalah. Kasus pencurian benda muatan kapal tenggelam (BMKT) di perairan Indonesia telah berlangsung sejak awal perkembangan arkeologi bawah laut di era 70 -an, dan masih berlangsung hingga saat ini. Melihat potensi dan permasalahan cagar budaya bawah air yang semakin menghawatirkan, maka sangat diperlukan landasan hukum yang kuat untuk melindunginya. Ketika hukum dan perundangan cagar budaya bawah air tidak cukup kuat untuk melindunginya, maka Indonesia yang kaya benda cagar budaya bawah air akan kehilangan banyak data sejarah. Tulisan ini akan mengulas undang-undang yang terkait dengan cagar budaya bawah air dan menawarkan beberapa poin kritik yang dapat dijadikan acuan dalam merevisi undang-undang tersebut.
\end{abstract}

Kata kunci: BMKT, perundangan, arkeologi, bawah laut.

Abstract : A research by UNESCO finds that there are \pm 3000 shipwreck sites in Indonesian water territory. This finding was also supported by the fact that Indonesia is located between the crossings of two oceans and continents. Hence, Indonesian water territory has become a strategic international trade route for centuries. This condition is an advantage and a problem as well. Since the 70's until now, a lot of shipwreck sites robbery cases had happened. Considering those potentials and the threats on the Indonesian underwater cultural heritage, the need for strong law enforcement is inevitable. Without the strong law enforcement, Indonesian will lose most of its invaluable historical data. This writings will reviews the laws regard to the underwater cultural heritage and then propose some critical points for future revisions.

Key words: Underwater cultural heritage, law, Archeology, underwater.

\section{PENDAHULUAN}

Indonesia sebagai negara kepulauan terbesar di dunia memiliki wilayah laut yang lebih luas dibandingkan wilayah daratan. Terbukti dari keseluruhan luas wilayah Indonesia yang terbentang sepanjang 3.977 mil antara Samudra Hindia dan Samudra Pasifik, 75\% adalah laut. Wilayah laut yang mendominasi, serta posisi strategis yang berada di antara jalur persilangan dua benua, menjadikan wilayah perairan Indonesia pada masa lalu ramai dilayari kapal-kapal asing. Kondisi ini tercatat di berbagai sumber sejarah, baik catatan para penjelajah Eropa maupun informasi dari utusan kekaisaran China seperti Ma Huan, I Tsing, maupun Laksamana Ceng Ho yang menyebutkan bahwa sejak abad ke-5 M perairan Nusantara merupakan jalur pelayaran dagang internasional (Reid, 2011: 5). Kapal-kapal berlayar dari wilayah Mediterania, India, dan Afrika menuju bandar-bandar di perairan Nusantara untuk mencari rempah-rempah, kapur barus maupun emas di Pulau Sumatera. Wilayah Nusantara pada masa lalu dikenal dengan istilah negeri di bawah angin. Istilah ini juga merujuk pada suatu wilayah yang memiliki jenis rempah yang paling mahal dan langka: cengkeh, pala, dan bunga pala (Turner, 2011: 29).

Ahli sejarah lain seperti Reid dalam bukunya Southeast Asia in the Age of Commerce (1450-1680), memaparkan bahwa wilayah Indonesia pada kurun niaga merupakan wilayah yang lalu lintasnya paling sibuk. Banyak bandar-bandar yang ramai disinggahi kapal-kapal asing mulai dari Aceh hingga Maluku (Reid, 2011: 18). Para penjelajah dan pedagang Arab juga banyak memberitakan dalam catatancatatan tentang ramainya perairan Nusantara dan kekayaan alamnya yang luar biasa. Beberapa catatan 
penjelajah Arab seperti yang dtuliskan oleh Masudi (890-956 M) mengatakan bahwa, tidak ada kerajaan lain yang memiliki lebih banyak sumber daya alam dan komoditas ekspor dibanding wilayah ini. Harta mereka antara lain adalah kapur barus, pohon gaharu, cengkih, kayu cendana, buah pinang, bunga pala, kemukus, dan sebangsanya. Terbukti dari catatan para penjelajah bangsa Eropa, China, dan Arab ini, perairan Nusantara memang benar pernah menjadi jalur perdagangan internasional yang ramai pada masa itu (Turner, 2011: 30).

Sea network atau jaringan lalulintas laut perairan Nusantara terbentuk atas kebutuhan terhadap komoditas-komoditas yang paling dicari di masa itu, yakni rempah, emas dan hasil hutan yang unik dan langka. Perdagangan merupakan proses pertukaran komoditas yang beragam antar satu bangsa dengan bangsa lain yang memiliki kebudayaan berbeda-beda. Wilayah Nusantara hadir sebagai surga hasil hutan dan rempah-rempah yang paling dicari di seluruh dunia, dan hal inilah yang kemudian melayarkan ribuan kapal di atas perairan Nusantara. Kondisi ini juga berdampak pada tumbuh dan berkembangnya kotakota pelabuhan seperti Sriwjiaya, Batavia, maupun Makassar pada kurun waktu yang berbeda-beda. Pada abad ke-7 M muncul Kerajaan Sriwijaya yang terkenal memiliki armada laut raksasa yang sengaja dibentuk untuk menguasai jalur pelayaran strategis di sepanjang perairan Sumatera. Ramainya arus lalulintas laut menjadikan Kerajaan Sriwijaya lebih tergantung dari pola perdagangan dan pembayaran pajak pelabuhan dari pada pertanian dan hasil hutan (Pusat Kajian Sejarah dan Budaya Maritim Asia Tenggara, 2003: 69). Sedangkan pada abad ke-16 M muncul Batavia yang juga mengandalkan posisi strategisnya sebagai sentral dan pusat transit perdagangan. Di sana gudang-gudang rempah, galangan perbaikan kapal dan pelabuhan-pelabuhan besar dibangun untuk memenuhi kebutuhan perdagangan dan pelayaran (Knaap, 1996: 87).

Beberapa arsip di negara-negara Eropa dan China mencatat bahwa proses kurun niaga ini berlangsung selama ratusan tahun. Selain itu pada laporan-laporan arsip tersebut juga tercatat bahwa banyak kapal dagang yang tenggelam di sepanjang wilayah perairan Indonesia. Penyebab tenggelamnya kapal bisa diakibatkan oleh berbagai macam faktor, seperti misalnya badai, perang, maupun karena kelalaian awak kapal (Utomo, 2008: 18). Pernyataan ini semakin kuat dengan data Kementerian Kelautan dan Perikanan yang menyebutkan bahwa terdapat sekitar 493 titik kapal karam di sepanjang perairan Indonesia yang berisi benda muatan kapal tenggelam (selanjutnya disebut dengan BMKT). Titik-titik ini tersebar dari Sabang hingga Merauke. Akan tetapi berdasarkan data yang dikumpulkan oleh UNESCO menyebutkan bahwa ada lebih dari 3.000 titik kapal tenggelam yang berisi BMKT di perairan Indonesia. Dari jumlah titik kapal karam yang diduga mengandung BMKT yang begitu melimpah, tentu akan mengundang berbagai macam persoalan, baik pencurian maupun perusakan. Beberapa contoh kasus pengangkatan BMKT terjadi pada tahun 1985, yakni pengangkatan pada kapal Geldermalsen milik VOC yang tenggelam di perairan Haliputan, Tanjung Pinang, serta kasus pengangkatan BMKT di perairan Cirebon pada April 2004 sampai Agustus 2005 (Utomo, 2008: 30).

Dari hasil pengangkatan BMKT di perairan Cirebon yang dilakukan P.T. Paradigma Putra Sejahtera bekerja sama dengan seorang kolektor asing bernama Michaele Hatcher, maka pada 5 Mei 2010 telah berhasil dilelang \pm 271.381 benda muatan kapal tenggelam. Akibat dari pelelangan ini banyak bermunculan protes dari publik, terutama kalangan pecinta budaya dan arkeolog. Kasus-kasus serupa sebenarnya telah banyak terjadi diperairan Nusantara, namun banyak yang tidak diketahui oleh publik. Misalnya saja pengangkatan kapal Tek Sing pada tahun 1999 oleh Hatcher yang juga dianggap ilegal oleh sebagian besar pemerhati hukum dan cagar budaya, namun bisa lepas dari jeratan hukum. Melihat kasus-kasus tersebut, maka muncul satu pertanyaan besar, ada apa dengan undang-undang kita? Apakah kita belum mempunyai hukum yang mengatur serta melindungi persoalan pengangkatan ataupun pemanfaatan BMKT secara spesisfik? Oleh karena itu tulisan ilmiah ini mencoba menguak sekelumit persoalan tinggalan cagar budaya bawah air dalam analisis hukum. Kiranya kajian sederhana ini bisa 
memberikan pemahaman dan pembuka pemikiran masyarakat yang masih awam mengenai perundangan dan perlindungan cagar budaya bawah air.

\section{Analisis Hukum Cagar Budaya Bawah Air}

Sebagai Negara kepulauan dengan wilayah laut seluas 5,8 juta $\mathrm{Km}^{2}$ yang di dalamnya terkandung sumber daya laut hayati dan non hayati yang berlimpah, maka dibutuhkan undang-undang yang memayungi dan melindungi wilayah maritim Indonesia berikut sumber daya di dalamnya. Adapun dasar hukum yang pertama dibentuk setelah Indonesia memproklamasikan kemerdekaannya adalah Undang-Undang Dasar 1945. Namun hukum yang secara spesifik menyangkut bidang kelautan khususnya cagar budaya bawah air baru muncul ketika Deklarasi Juanda ditandatangani Perdana Menteri Juanda pada 13 Desember 1957. Deklarasi Juanda dicetuskan untuk memperjuangkan hak-hak kelautan Indonesia di mata hukum internasional. Perjuangan panjang itu akhirnya terwujud dengan ditandatanganinya Konvensi Hukum Laut PBB (UNCLOS) pada 10 Desember tahun 1982 (Djalal, 2010: 17).

Konvensi Hukum Laut 1982 (UNCLOS) berperan sangat penting dalam pelindungan wilayah Indonesia yang berbentuk kepulauan. Berdasarkan pengakuan internasioanl tersebut, Indonesia telah diberikan kewenangan wilayah laut seluas 12 mil dan Zona Ekonomi Ekslusif (ZEE) 200 mil (Djalal,

\section{Tabel 1. Perbandingan Undang-Undang No. 5 Tahun 1992 dengan Undang-Undang No. 11 Tahun 2010 terkait Tingalan} Bawah Laut/Air.

\begin{tabular}{|c|c|}
\hline Undang-Undang No. 5 Tahun 1992 & Undang-Undang No. 11 Tahun 2010 \\
\hline $\begin{array}{l}\text { Pasal 1ayat (2). Situs adalah lokasi yang mengandung } \\
\text { atau diduga mengandung benda cagar budaya termasuk } \\
\text { lingkungannya yang diperlukan bagi pengamanannya }\end{array}$ & $\begin{array}{l}\text { Pasal } 1 \text { ayat (5). Situs Cagar Budaya adalah lokasi yang } \\
\text { berada di darat dan/atau di air yang mengandung Benda } \\
\text { Cagar Budaya, Bangunan Cagar Budaya sebagai hasil } \\
\text { kegiatan manusia atau bukti kejadian pada masa lalu. }\end{array}$ \\
\hline $\begin{array}{l}\text { Pasal } 6 \text { ayat (1). Benda Cagar Budaya dapat dimiliki } \\
\text { atau dapat dikuasai oleh setiap orang dengan tetap } \\
\text { memperhatikan fungsi sosialnya dan sepanjang tidak } \\
\text { bertentangan dengan ketentuan dalam undang-undang ini }\end{array}$ & $\begin{array}{l}\text { Pasal } 12 \text { ayat (1). Setiap orang dapat memiliki dan/atau } \\
\text { menguasai Benda Cagar Budaya, Bangunan Cagar Budaya, } \\
\text { Struktur Cagar Budaya, dan/atau Situs Cagar Budaya dengan } \\
\text { tetap memperhatikan fungsi sosialnya sepanjang tidak } \\
\text { bertentangan dengan ketentuan undang-undang ini. }\end{array}$ \\
\hline $\begin{array}{l}\text { Pasal } 6 \text { ayat (2). a. Dimiliki atau dikuasai secara turun } \\
\text { temurun atau merupakan warisan.,b. jumlah untuk setiap } \\
\text { jenisnya cukup banyak dan sebagian telah dimiliki oleh } \\
\text { negara. }\end{array}$ & $\begin{array}{l}\text { Pasal } 12 \text { ayat (2). Setiap orang dapat memiliki dan/atau } \\
\text { menguasai Cagar Budaya apabila jumlah dan jenis Cagar } \\
\text { Budaya, Bangunan Cagar Budaya dan/atau Situs Cagar } \\
\text { Budaya telah memenuhi kebutuhan negara. }\end{array}$ \\
\hline $\begin{array}{l}\text { Pasal } 6 \text { ayat (4). Warga negara asing, yang dapat } \\
\text { memiliki atau dikuasai adalah hanya benda cagar budaya } \\
\text { sebagaimana pada pasal } 6 \text { ayat (2) dikuasai secara turun } \\
\text { temurun dan jumlahnya banyak dan sebagian telah dikuasai } \\
\text { Negara }\end{array}$ & $\begin{array}{l}\text { Pasal } 14 \text { ayat (1). Warga negara asing dan/atau badan } \\
\text { hukum asing tidak dapat memiliki dan/atau menguasai Cagar } \\
\text { Budaya, kecuali warga negara asing dan/atau badan hukum } \\
\text { asing yang tinggal menetap di wilayah Negara kesatuan RI }\end{array}$ \\
\hline $\begin{array}{l}\text { Pasal } 7 \text { ayat (3). Ketentuan mengenai tata cara pengalihan } \\
\text { dan pemberian imbalan sebagaimana dimaksud, ditetapkan } \\
\text { dengan Peraturan Pemerintah }\end{array}$ & $\begin{array}{l}\text { Pasal } 17 \text { ayat (1). Setiap orang dilarang mengalihkan } \\
\text { kepemilikan Cagar Budaya peringkat nasional, provinsi, } \\
\text { atau kabupaten kecuali dengan izin Menteri, Gubernur, atau } \\
\text { Bupati/Walikota. }\end{array}$ \\
\hline $\begin{array}{l}\text { Pasal } 12 \text { ayat (1). Setiap orang dilarang mencari benda cagar } \\
\text { budaya atau benda berharga yang tidak diketahui pemiliknya } \\
\text { dengan cara penggalian, penyelaman, pengangkatan, atau } \\
\text { dengan cara pencarian lainnya tanpa izin dari pemerintah. }\end{array}$ & $\begin{array}{l}\text { Pasal } 26 \text { ayat (4). Setiap orang dilarang melakukan } \\
\text { pencarian Cagar Budaya atau yang diduga Cagar Budaya } \\
\text { dengan penggalian, penyelaman, dan/atau pengangkatan } \\
\text { di darat dan/atau di air kecuali dengan izin pemerintah atau } \\
\text { pemerintah daerah sesuai dengan kewenangannya. }\end{array}$ \\
\hline $\begin{array}{l}\text { Pasal } 15 \text { ayat (2). Tanpa izin pemerintah setiap orang } \\
\text { dilarang; membawa benda cagar budaya ke luar wilayah } \\
\text { Republik Indonesia. }\end{array}$ & $\begin{array}{l}\text { Pasal } 68 \text { ayat (1). Cagar Budaya, baik seluruh maupun } \\
\text { bagian-bagiannya, hanya dapat dibawa ke luar wilayah } \\
\text { RI untuk kepentingan penelitian, promosi budaya dan/atau } \\
\text { pameran. }\end{array}$ \\
\hline $\begin{array}{l}\text { Pasal } 26 \text { ayat (1). Barang siapa sengaja merusak, membawa, } \\
\text { memindahkan tanpa izin pemerintah dipidana dengan } \\
\text { pidana penjara selama-lamanya } 10 \text { tahun dan denda setingi- } \\
\text { tingginya } 100 \text { juta. }\end{array}$ & $\begin{array}{l}\text { Pasal } 109 \text { ayat (1). Setiap orang tanpa izin menteri, } \\
\text { membawa Cagar Budaya ke luar wilayah RI sebagaimana } \\
\text { dimaksud pasal } 68 \text {, dipidana penjara minimal enam bulan dan } \\
\text { denda paling sedikit } 200 \text { juta. }\end{array}$ \\
\hline
\end{tabular}


2010: 25). Kewenangan ini sangat memungkinkan bagi Indonesia untuk mengelola serta melindungi ruang-ruang laut, dasar laut (bawah laut), dan ruang di atas lautnya. Ruang laut Indonesia, baik di atas maupun bawah laut mempunyai nilai yang sangat strategis. Misalnya pada ruang di bawah laut terdapat ribuan kapal karam dengan BMKT yang bernilai histori dan ekonomis. Namun prospek pengelolaan dan pelindungan benda berharga dasar laut Indonesia belum banyak diselidiki dan dimanfaatkan (Djalal, 2010: 39).

Sejauh ini terdapat beberapa landasan hukum yang digunakan dalam melindungi dan memanfaatkan cagar budaya bawah air, namun seperti permasalahan yang diajukan pada tulisan ini, apakah landasan hukum cagar budaya bawah air tersebut cukup kuat dan sesuai? Selanjutnya persoalan tersebut dapat kita lihat dari analisis hukum cagar budaya bawah air di bawah ini.

\section{1. Undang-Undang Nomor 5 Tahun 1992 dan} Nomor 11 Tahun 2010

Sebelum Undang-Undang No. 11 Tahun 2010 tentang Cagar Budaya dikeluarkan, perundangan yang mengatur perihal Benda Cagar Budaya adalah Undang-Undang No. 5 Tahun 1992. Antara kedua perundangan ini terdapat perbedaan yang cukup signifikan, dimana Undang-Undang No. 11 Tahun 2010 lebih mengangkat pembahasan pelindungan cagar budaya bawah air dibanding Undang-Undang No. 5 Tahun 1992. Adapun pemaparan perbedaan keduanya dalam hal pelindungan tinggalan bawah laut tersaji di Tabel 1.

Undang-Undang No. 11 Tahun 2010 dalam pasal-pasalnya telah jelas menyebutkan tentang cagar budaya bawah air. Hal ini terlihat pada penjelasan mengenai situs dan benda cagar budaya pada pasal 1 . Sedangkan dalam Undang-Undang No. 5 Tahun 1992 dalam penjelasannya mengenai situs belum begitu menekankan perhatiannya pada cagar budaya bawah air. Pasal 12 ayat (1) Undang-Undang No. 5 Tahun 1992 mengenai pencarian disebutkan, "setiap orang dilarang mencari benda cagar budaya atau benda berharga yang tidak diketahui pemiliknya dengan cara pengalihan, penyelaman, pengangkatan, atau dengan cara lainnya, tanpa seizin dari pemerintah". Barulah pada pasal 12 Undang-Undang No. 5 Tahun 1992 mulai disinggung mengenai cagar budaya bawah air baik berupa shipwreck ataupun BMKT-nya, dengan menyebut kata 'penyelaman', sedangkan dalam pasal-pasal sebelumnya terkait cagar budaya bawah air sama sekali tidak disebutkan. Berbeda dengan Undang-Undang No. 11 Tahun 2010 yang sejak pasal-pasal awalnya telah menjelaskan mengenai keberadaan dan posisi cagar budaya bawah air dalam pelindungan hukum.

Pasal 26 ayat (1) Undang-Undang No. 5 Tahun 1992 mengenai pencarian menegaskan, bahwa pengangkatan tanpa seizin pemerintah akan dipidana dengan pidana penjara selama-lamanya 10 tahun dan/atau denda setinggi-tingginya 100 juta. Apabila dibandingkan dengan Undang-Undang No.11 Tahun 2010, sanksi (efek jera) yang diberikan tidak jauh berbeda, penjara selama-lamanya 10 tahun dan denda setingi-tingginya 1,5 miliar. Ketentuan lain UndangUndang No. 5 Tahun 1992 tidak memaparkan pasal lain terkait cagar budaya bawah air, walaupun pada masa-masa sebelumnya telah banyak terjadi kasus pencurian BMKT di perairan Indonesia.

Pada pasal 14 ayat (1) menegaskan bahwa warga negara asing dilarang memindahkan atau membawa benda cagar budaya termasuk tinggalan cagar budaya bawah air keluar dari wilayah Negara Kesatuan Republik Indonesia. Namun pada pasal 17, dan 67 Undang-Undang No. 11 Tahun 2010 ditambahkan kalimat "kecuali dengan izin menteri, gubernur, bupati/walikota”. Pasal-pasal sebelumnya jelas telah melarang pengangkatan, penguasaan, pencurian dan membawa, namun pada pasal 17 diberikan ruang abuabu untuk penguasaan dan membawa cagar budaya bawah laut apabila ada surat izin dari menteri, gubernur, bupati/walikota. Tidak mengherankan apabila Hatcher dalam beberapa wawancara bersama media tidak merasa melakukan pencurian, walaupun seluruh publik Indonesia telah menghujatnya sebagai pencuri.

Michael Hatcher menyebut dirinya sebagai arkeolog maritim yang suka bisnis barang antik. Aktifitas pencarian harta karun yang dia lakukan telah 
banyak diberitakan di berbagai media internasional. Misalnya pada percetakan Inggris, Hamish Hamilton Ltd., yang mempublikasikan kisah petualangan dan temuan Hatcher bertajuk "The Nanking Cargo", sebutan untuk kargo kapal VOC Geldermalsen yang berisi barang-barang berharga hasil transaksi perdagangan VOC di Nanking, China (Kompas, 4 September 2009). Berdasarkan analisis UndangUndang No. 5 Tahun 1992 dan Undang-Undang No. 11 Tahun 2010, serta dikaitkan dengan beberapa kasus pengangkatan BMKT di perairan Indonesia, maka muncul sebuah pertanyaan besar yang patut kita renungkan, apakah Undang-Undang No. 11 Tahun 2010 cukup kuat untuk melindungi cagar budaya bawah air kita? Atau jangan-jangan tidak ada bedanya dengan Undang-Undang No. 5 Tahun 1992?

\section{2. Keputusan Presiden No. 25 Tahun 1992}

Sebelum kita beranjak pada Keppres No. 12 Tahun 2009 terkait pengangkatan dan pemanfaatan BMKT ada baiknya terlebih dahulu kita merujuk pada Keppres pendahulunya yakni Keppres No. 25 Tahun 1992. Keppres No. 25 Tahun 1992 adalah peraturan pemerintah yang dikeluarkan mengenai pembagian hasil pengangkatan BMKT antara pemerintah dengan perusahaan (P.T.) terkait. Pada pasal 1 Keppres No. 25 Tahun 1992 disebutkan, bahwa benda muatan kapal tenggelam dianggap sebagai benda cagar budaya yang dilarang diperjualbelikan dan harus diserahkan kepada Negara. Kemudian pada pasal 2, berdasarkan ketentuan peraturan perundangundangan yang berlaku (Undang-Undang No. 5 Tahun 1992) diperbolehkan dijual asal dimuka umum dan dengan perantara kantor lelang Negara atau balai lelang internasional setelah memperoleh persetujuan panitia nasional (selanjutnya disebut PANNAS) sebagaimana dimaksud dalam Keppres No. 43 Tahun 1983. Selanjutnya hasil penjualan benda berharga sebagaimana dimaksud dalam ayat (1), dibagi antara pemerintah dengan perusahaan (P.T.) terkait dengan bentuk perhitungan sebagai berikut:

- $50 \%$ (lima puluh persen) dari hasil kotor/bruto, diperuntukkan bagi Pemerintah dan harus disetor ke Kas Negara.
- $50 \%$ (lima puluh persen) dari hasil kotor/bruto, sisanya merupakan hak perusahaan.

Merujuk pada Keppres No. 43 Tahun 1983 di atas, kemungkinan perdagangan BMKT dalam bentuk pelelangan sudah dimuali sejak tahun 1983 . Cukup jelas bahwa benda cagar budaya bawah air masih dijadikan lahan pencarian keuntungan dan masih diangap sebagai harta karun yang menggiurkan, bukan dianggap sebagai benda warisan budaya yang bernilai sejarah dan ilmu pengetahuan. Lantas bagaimana dengan Keppres sejenis yang dikelurkan pada waktu kemudian, yakni Keppres No. 12 Tahun 2009. Apakah lebih tegas dan memihak kepada pelindungan cagar budaya bawah air?

\section{3. Keputusan Presiden No. 12 Tahun 2009}

Keputusan Presiden No. 12 Tahun 2009 merupakan perubahan atas Keputusan Presiden No. 19 Tahun 2007 mengenai Panitia Nasional Pengangkatan dan Pemanfaatan BMKT. Peraturan ini mengacu pada Undang-Undang Dasar 1945 pasal 4 ayat (1) dan undang-undang No. 17 Tahun 1985 tentang Pengesahan Konvensi Hukum Laut Internasional Tahun 1982 (UNCLOS), dan masih mengacu pada Undang-Undang No. 5 Tahun 1992. Undang-Undang terkait lainnya adalah UndangUndang No. 6 Tahun 1996 tentang Perairan dan Kelautan, Undang-Undang No.1 Tahun 2004 tentang Perbendaharaan Negara, Undang-Undang No. 32 Tahun 2004 tentang Pemerintah Daerah (Otonomi Daerah). Beberapa pasal dalam Keppres No. 12 Tahun 2009 yang patut kita analisa antara lain sebagai berikut:

- Pasal 2 ayat (1), BMKT merupakan benda yang dikuasai Negara Kesatuan Republik Indonesia dan dikelola oleh Pernerintah.

- Pasal 2 ayat (2), BMKT memenuhi unsur-unsur: a) Nilainya sangat penting bagi sejarah, ilmu pengetahuan, dan kebudayan bangsa Indonesia. b) Sifatnya memberikan corak khas dan unik. c) Jumlah dan jenisnya sangat terbatas dan langka. Berdasarkan peraturan perundang-undangan di bidang benda cagar budaya, BMKT dinyatakan menjadi milik negara. 
Adapun PANNAS adalah panitia nasional yang dalam hal ini bertugas dalam pengangkatan dan pemanfaatan BMKT yang selanjutnya diatur pada pasal 4;

- Ayat (1), PANNAS BMKT mempunyai tugas:

a) Mengkoordinasikan kegiatan departemen dan instansi lain yang berkaitan dengan kegiatan pengelolaan BMKT, b) Menyiapkan peraturan perundang-undangan dan penyempurnaan kelembagaan di bidang pengelolaan BMKT, c) Memberikan rekomendasi mengenai izin survei, pengangkatan, dan pemanfaatan BMKT kepada pejabat yang berwenang sesuai dengan ketentuan peraturan perundang-undangan, d) Menyelenggarakan koordinasi kegiatan pemantauan, pengawasan, dan pengendalian atas proses survei, pengangkatan dan pemanfaatan BMKT, e) Menyampaikan laporan tertulis pelaksanaan tugas paling sedikit 1 (satu) tahun sekali kepada presiden.

- Ayat (2), PANNAS BMKT memanfaatkan BMKT yang tidak dinyatakan sebagai milik negara sesuai dengan ketentuan peraturan perundang-undangan.

- Ayat (3), Dalam melaksanakan tugasnya, PANNAS BMKT dapat mengundang dan/ atau meminta pendapat dan instansi pemerintah dan/atau pihak lain.

Dari uraian peraturan perundangan di atas jelas terlihat apa yang dimaksud dengan BMKT berikut kriterianya dan juga disebutkan mengenai pembentukan PANNAS yang menangani sekaligus bertanggung jawab pada pengangkatan dan pemanfaatan BMKT. Namun dalam kasus pengangkatan kapal Cirebon yang dimulai dari tahun 2004 sampai 2005, dan kemudian hasilnya dilelang di Balai Lelang Christie, Belanda pada tahun 2010, kemungkinan besar PANNAS ikut serta di dalamnya. Demikian juga dengan kasus sebelumnya, yakni pengangkatan kapal Tek Sing Cargo yang juga dipimpin Hatcher pada tahun 19971998 di Selat Galasa Bangka-Belitung, PANNAS juga kemungkinan terlibat dengan mengeluarkan surat izin pengangkatan (Utomo, 2008: 22).

Kasus-kasus penggangkatan atau pencurian
BMKT yang terjadi di perairan Indonesia cukup sering menghebohkan dunia Internasional dan banyak dikecam publik. Bagaimana mungkin benda bersejarah sebanyak \pm 450.000 buah tiba-tiba sudah diangkat ke Australia oleh Hatcher tanpa diketahui oleh pihak instansi yang bertanggung jawab. Akhirnya sejumlah \pm 450.000 buah benda bersejarah lalu dipaketkan ke dalam 43 kontainer untuk diangkat ke Balai Lelang Negel Auction di Stuttgart, Jerman (Utomo, 2008: 22). Publik Indonesia untuk kesekian kalinya hanya bisa mengecam melihat kasus pencurian BMKT yang benilai sejarah dan ilmu pengetahuan. Kasus pencurian dan pelelangan BMKT seperti ini masih terus berlangsung, bahkan menjadi tren tersendiri bagi para pencari harta karun seperti Hatcher, dimana perairan Nusantara sering diibaratkan bagai toko tanpa penjaga.

\subsection{Peraturan Menteri Keuangan No.184/ PMK.06/2009}

Peraturan yang dikeluarkan oleh menteri keuangan ini menyangkut tentang tata cara penetapan status penggunaan dan penjualan benda berharga asal muatan kapal tenggelam yang merujuk pada perundangan: Undang-Undang No. 5 Tahun 1992 tentang Benda Cagar Budaya. Keputusan Presiden No. 19 Tahun 2007 juga termasuk tentang pembentukan PANNAS BMKT sebagaimana termuat dalam pasalpasal Keputusan Presiden No. 12 Tahun 2009, sebagai berikut:

Pasal 1, ayat:

- (2) Benda Berharga Asal Muatan Kapal Yang Tenggelam, yang selanjutnya disebut BMKT, adalah benda berharga yang memiliki nilai sejarah, budaya, ilmu pengetahuan, dan ekonomi, yang tenggelam di wilayah perairan Indonesia, zona ekonomi eksklusif Indonesia dan landas kontinen Indonesia, paling singkat berumur 50 (lima puluh) tahun.

- (3) Barang Milik Negara, selanjutnya disebut BMN, adalah semua barang yang dibeli dari APBN atau berasal dan perolehan lain yang sah. 
Pasal 2

Maksud dan tujuan diterbitkannya Peraturan Menteri Keuanganiniadalah untuk mewujudkan kepastian hukum dalam penetapan status penggunaan dan penjualan BMKT secara tertib, terarah, dan akuntabel untuk meningkatkan penerimaan negara dan/atau sebesar-besarnya kesejahteraan rakyat.

Pasal 4, ayat:

- (1) Menteri Keuangan, Menteri Kebudayaan dan Pariwisata, dan Menteri Kelautan dan Perikanan melakukan penanganan hasil pengangkatan BMKT sesuai ketentuan peraturan perundang-undangan.

- (2) Pelaksanaan penanganan hasil pengangkatan BMKT sebagaimana dimaksud pada ayat (1) dapat dikoordinasikan dengan Kementerian Negara/Lembaga, PANNAS BMKT, Pemerintah Provinsi, Pemerintah Kabupaten/Kota, dan/atau pihak terkait lainnya.

Pasal 5, ayat:

- (1) Dalam rangka penanganan hasil pengangkatan BMKT sebagaimana dimaksud dalam Pasal 4 ayat (1), Menteri Keuangan memiliki kewenangan sebagai berikut: a) Menetapkan status penggunaan BMKT berstatus BMN, b) Memberikan persetujuan pelaksanaan penjualan BMKT berstatus BMN non koleksi negara, c) Memberikan persetujuan pelaksanaan penjualan BMKT berstatus selain BMN.

- (2) Kewenangan sebagaimana dimaksud pada ayat (1) secara fungsional dilaksanakan oleh Direktur Jenderal Kekayaan Negara.

Pasal 7;

Persetujuan pelaksanaan penjualan sebagaimana dimaksud dalam Pasal 5 ayat (1) huruf b diberikan sesuai ketentuan peraturan perundang-undangan.

Pasal 8;

Persetujuan pelaksanaan penjualan sebagaimana dimaksud dalam Pasal 5 ayat (1) huruf c diberikan berdasarkan permohonan dari
Menteri Kelautan dan Perikanan.

Berdasarkan pemaparan pasal-pasal yang dikeluarkan Kementrian Keuangan terkait posisi BMKT dan proses penjualannya, jelas tidak memihak kepada pelestarian dan pelindungan, namun justru lebih pada pencarian keuntungan ekonomi. Peraturan Menteri Keuangan ini juga masih berpatokan pada Undang-Undang No. 5 Tahun 1992 yang sangat sedikit mengangkat dan memperhatikan cagar budaya bawah air. Pada sisi lain, dapat juga dilihat bahwa antara Undang-Undang Cagar Budaya, Keppres No. 25 dan Keppres No. 12 terkait BMKT, dan Peraturan Menteri Keuangan justru terkesan tumpang tindih. Peraturan yang tumpang tindih ini dapat menimbulkan kerancuan dan kekacauan di lapangan, alhasil tidak dapat melindungi cagar budaya bawah air.

\section{Konvensi Internasional Pelindungan Tinggalan Bawah Laut/Air Tahun 2001}

Konferensi PBB tentang hukum laut (UNCLOSS) Tahun 1982, mewajibkan Negara -pihak yang memiliki warisan budaya bawah lautuntuk melindunginya walaupun tidak disebutkan secara spesifik. Maraknya pecurian BMKT di berbagai belahan dunia memaksa PBB untuk mengeluarkan konvensi internasional terkait aturan mendasar dalam rangka pelestarian terhadap cagar budaya bawah air. Konvensi diselenggarakan oleh UNESCO pada tahun 2001 di Paris (UNESCO, 2001).

Adapun prinsip-prinsip umumnya antara lain adalah:

1. Negara pihak konvensi berjanji untuk melindungi warian budaya bawah air dan dimanfaatkan untuk kepentingan umat manusia.

2. Cagar budaya bawah air dilarang untuk dieksploitasi secara komersil untuk perdagangan dan spekulasi.

Prinsip-prinsip pelestarian in situ diatur pada bagian tertentu yang disebut "ANNEX" berisi peraturan mengenai kegiatan-kegiatan yang diarahkan pada cagar budaya bawah air, yaitu skema operasi untuk intervensi bawah air yang diakui secara internasional sebagai dokumen acuan dalam disiplin 


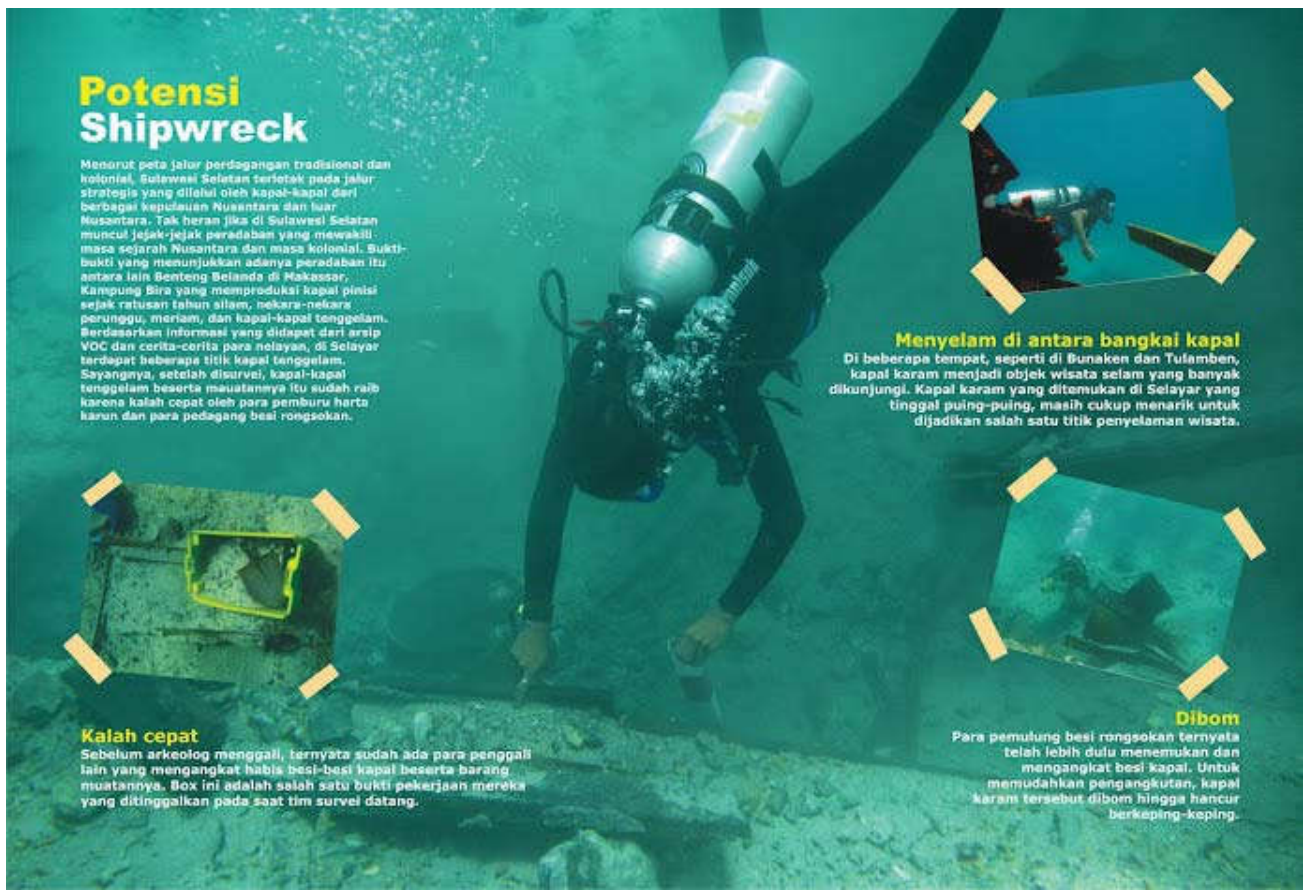

Foto 1. Gambaran potensi dan permasalahan cagar budaya bawah air di Indonesia (Sumber: http://divetowreck.blogspot.com).

arkeologi bawah air (UNESCO, 2001).

Konvensi pelindungan cagar budaya bawah air 2001 menetapkan standar pelindungan cagar budaya bawah air bagi semua negara yang telah meratifikasi, sekaligus secara otomatis hanya berlaku pada negaranegara yang telah meratifikasi konvensi. Indonesia sebagai negara kepulauan terbesar di dunia dengan jumlah situs kapal karam terbanyak, justru belum meratifikasi konvensi UNESCO 2001. Apabila meninjau peraturan yang dikemukakan dalam konvensi, secara umum tidak ada yang merugikan, namun justru sangat menguntungkan Indonesia

Tabel 2. Hasil pengangkatan BMKT kapal Cirebon. Sumber: Utomo, 2008: 35.

\begin{tabular}{|c|c|c|c|}
\hline No & Bahan & Jenis & Jumlah \\
\hline \multirow[t]{7}{*}{1} & Logam & $>$ Emas & $>$ \\
\hline & & $>\quad$ Perunggu & 252 \\
\hline & & $>\quad$ Besi & $>\quad 16$ \\
\hline & & $>$ Tembaga & 51 \\
\hline & & $>$ Timah & 9.926 \\
\hline & & $>$ Perak & 18 \\
\hline & & $>$ Koin & 4.950 \\
\hline \multirow[t]{8}{*}{2} & Batuan & $>$ Batu & $>\quad 50$ \\
\hline & & $>\quad$ Manik-manik & $>\quad 970$ \\
\hline & & $>\quad$ Pipisan & 21 \\
\hline & & $>$ Ruby & $>\quad 103$ \\
\hline & & $>$ Sapphire & $>\quad 127$ \\
\hline & & $>\quad$ Manik Coral & $>\quad 503$ \\
\hline & & $>\quad$ Manil Lapoz Lazuli & $>\quad 110$ \\
\hline & & $>\quad$ Lapiz Lazuli & $>723$ \\
\hline \multirow[t]{2}{*}{3} & Tanah Liat & $>$ Tembikar & 35.819 \\
\hline & & $>$ Keramik & 256.943 \\
\hline 4 & Kaca & $>\quad$ Artefak berbahan kaca & 3.067 \\
\hline 5 & Kayu & $>$ Frg. Kapal & $>\quad 19$ \\
\hline \multirow[t]{6}{*}{6} & Lain-lain & $>$ Gading & 59 \\
\hline & & $>$ Tulang/gigi & 281 \\
\hline & & $>$ Tanduk & $>10$ \\
\hline & & $>$ Rempah-rempah & $>\quad 28$ \\
\hline & & $>$ Bongkahan & $>\quad 39$ \\
\hline & & $>$ Unidentifield & $>76$ \\
\hline & Jumlah & & 314.171 \\
\hline
\end{tabular}




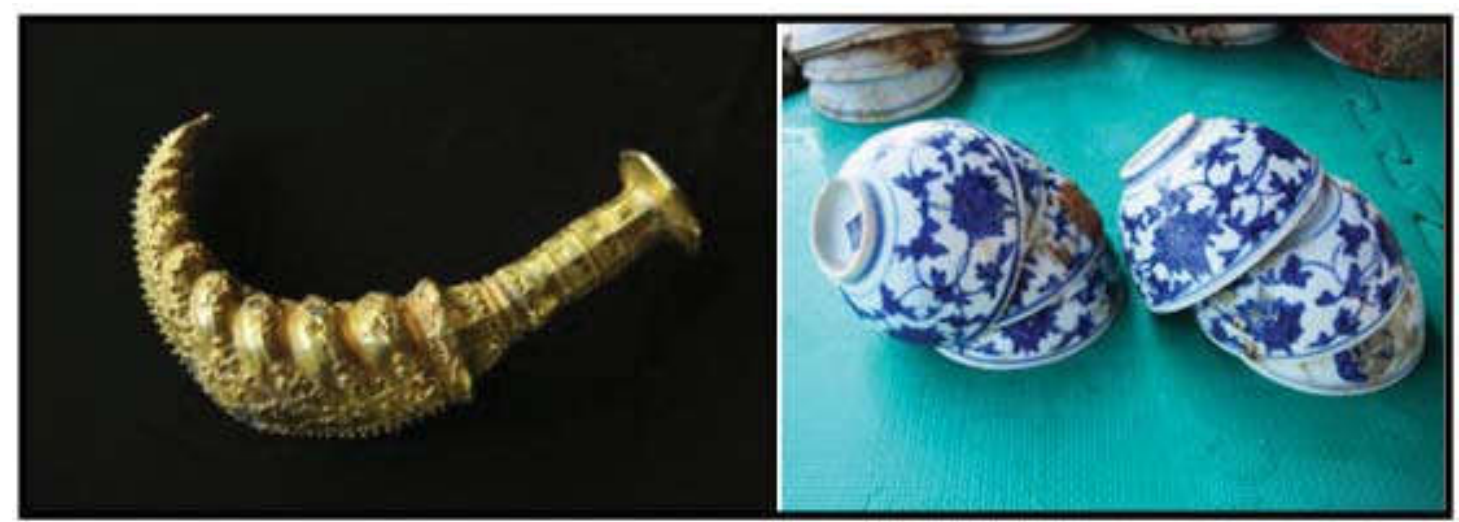

Foto 2. Benda Cagar Budaya hasil pengangkatan kapal Cirebon (Sumber: http://penjelajahbahari.blogspot.com).

sebagai negara yang memiliki banyak sumber BMKT. Sanksi hukum yang ditetapkan sangat melindungi, sehingga akan mampu membuat pencari harta karun seperti Hatcher berpikir dua kali sebelum melakukan pengangkatan. Disamping itu, konvensi juga akan mendorong sumber daya manusia Indonesia lebih giat dan serius mengurusi BMKT-nya. Namun mengapa Indonesia belum meratifikasi konvensi internasonal perlindungan bawah air tahun 2001?

\section{Studi Kasus: Pengangkatan BMKT Kapal Cirebon}

Pada surat kabar Jakarta Pos tertanggal 30 april 2010 halaman 2, disebutkan bahwa Menteri Kelautan Fadel Muhammad akan melelang artefak dari BMKT yang tenggelam di perairan Cirebon senilai 10 jt dolar AS berupa 271 keping artefak berharga. Pengangkatan bekerja sama dengan seorang bandit laut bernama Michael Hatcher yang diduga telah melakukan pencurian serupa pada 2.306 BMKT dan menjualnya ke pasar gelap dan investor asing. Pernyataan ini diungkapkan oleh Dirjen Pengawasan Sumber Daya Kelautan dan Perikanan Aji Sularso. pada Kamis 29 April 2010 Kasus pengangkatan BMKT di Cirebon yang dilakukan oleh P.T. Paradigma Putra Sejahtera (PPS) bekerjasama dengan Hatcher, dinilai sebagai kegiatan ilegal. Namun dalam proses hukum ternyata P.T. Paradigma Putra Sejahtera mampu menunjukkan surat izin melalui SK Menteri Kelautan dan Perikanan No.Kep.B.59/MENKP/ II/2004, tertanggal 19 Februari 2004. Menteri Kelautan dan Perikanan Freddy Numberi (ketika itu) yang sekaligus menjabat sebagai Ketua PANNAS BMKT, menilai kegiatan P.T. PPS dan Hatcher di perairan Cirebon adalah sah dan sesuai dengan aturan main yang ditetapkan PANNAS BMKT. Namun di sisi lain, pihak kepolisian tetap menganggap kegiatan tersebut melanggar hukum dengan merujuk pada Undang-Undang No. 5 Tahun 1992 tentang Benda Cagar Budaya (ketika itu) dan PP No. 10 Tahun 1993. Perbedaan persepsi masing-masing instansi justru semakin menimbulkan kebingungan dalam perlindungan cagar budaya bawah air. Daftar jenis barang muatan kapal Cirebon yang telah diangkat dan terdata, tersaji di Tabel 2.

\section{Kesimpulan dan Catatan}

Meskipun PANNAS BMKT sudah dibentuk cukup lama, serta telah tersedia payung hukum yang melindungi serta mengatur pengangkatan dan pemanfaatan cagar budaya bawah air, namun masih sering terjadi ketidaksesuaian pengangkatan BMKT di Indonesia, serta banyak dipengaruhi kepentingan ekonomi pribadi. Berikut beberapa persoalan yang dipandang perlu untuk segera dibenahi oleh semua stakeholder termasuk pihak pengusaha/investor:

1. Belum terciptanya harmonisasi dan sinkronisasi peraturan perundangan terkait cagar budaya bawah air, sehingga sering saling tumpang tindih.

2. Belum tersedianya data yang lengkap dan akurat terkait lokasi koordinat situs kapal karam beserta BMKT-nya yang terdapat di perairan Indonesia. 
3. Belum terlaksananya tindakan monitoring dan evaluasi pasca pengangkatan dan pemanfaatan cagar budaya bawah air yang sesuai dengan kaidah arkeologi.

4. Belum tegasnya peraturan perundangundangan dalam hal pelindungan dan prosedur pemanfaatan cagar budaya bawah air, termasuk tata cara pelaksanaan pelelangan yang sesuai konvensi internasional.

5. Sanksi hukum yang kurang tegas pada peraturan perundangan terkait cagar budaya bawah air.

6. Undang-Undang Cagar Budaya No.11 Tahun 2010 kiranya segera mengeluarkan PP terkait dengan pasal-pasal di dalamnya, khususnya pelindungan cagara budaya bawah air.

\section{Daftar Pustaka.}

Anwar, Chairul. 1989. Hukum

Internasional. Universitas Gadjah Mada. Yogyakarta.

Bowens, Amanda. 2009. The NAS Guide to Pinciples: Under WaterArcheology. Porthsmouth.

Djalal, Hasjim. 2010. Negara Kepulauan Menuju Negara Maritim. Lembaga Laut Indonesia. Jakarta.

Knaap, J Gerrit. 1996. Shallow Waters, Rising Tide. KITLV Press. Leiden.

Pusat Kajian Sejarah dan Budaya Maritim Asia Tenggara. 2003. Sejarah Maritim Indonesia. Departemen Kelautan dan Perikanan. Jakarta.

Reid, Anthony. 1993. Southeast Asia in the Age of Commerce, 1450 1680. Vol.11. Expansion and Crisis. New Haven. Yale University Press.

Turner, Jack. 2011. Sejarah Rempah: Dari Erotisme Sampai Imprealisme. Komunitas Bambu. Depok.

Utomo, Bambang Budi. 2008. Kapal Karam Abad Ke-10 di Laut Jawa Utara Cirebon. Panitia Nasional Pengangkatan BMKT. Jakarta.
7. Minimnya kuantitas dan kualitas arkeolog, mahasiwa arkeologi dan pihak terkait lainnnya dalam kajian maritim dan bawah air (menyelam, keahlian ekskavasi, dan konservasi bawah air).

8. Minimnya kegiatan sosialisasi perundangan terkait tinggalan cagar budaya bawah air kepada masyarakat umum, khususnya pada masyarakat pesisir.

9. Belum dikeluarkannya undang-undang kelautan.

10. Belum dilakukannya ratifikasi konvensi internasional pelindungan cagar budaya bawah air tahun 2001.

Perundangan dan Hukum Internasional

Hukum Laut Internasional Tahun 1982 (UNCLOS)

Keputusan Presiden No. 25 Tahun 1992

Keputusan Presiden No. 12 Tahun 2009

Konvensi Internasional Perlindungan Cagar Budaya Bawah Air Tahun 2001

Peraturan Menteri Keuangan No. 184/PMK. 06/2009. Undang-Undang No. 5 Tahun 1992 tentang Benda Cagar Budaya

Undang-Undang No. 11 Tahun 2010 tentang Cagar Budaya

Anonim, Majelis umum PBB sesi 53 Dokumen 456/Samudera dan Hukum Laut - Laporan Sekretaris Jenderal, Hal-61. 1998

Harian Kompas edisi 4 Sepetember 2009 http://formalcbc.wordpress.corn/2008/04/07/bcb-diperairan-cirebon/

www.budpar. go. id www.jakartapos.com http;//divetowreck.blogspot.com http;//penjelajahbahari.blogspot.com 